\title{
The key attributes of processing parameters on semi-solid metal casting: An Overview
}

\author{
Devendra Pratap Singh ${ }^{1,2,3 *}$ Vijay Kumar Dwivedi ${ }^{1}$, and Mayank Agarwal ${ }^{4}$ \\ ${ }^{1}$ GLA University, Mathura 281406, India \\ ${ }^{2}$ Pranveer Singh Institute of Technology, Kanpur 209305, India \\ ${ }^{3}$ Dr. A.P.J. Abdul Kalam Technical University, Lucknow 226031, India \\ ${ }^{4}$ Institute of Engineering Technology, Dr. Ram Manohar Lohia Avadh University, Ayodhya, India
}

\begin{abstract}
Commercialization of the developed technology is a prime factor for any nation and sector to retain its existence in this global economy. Day by day the technological advancement touching new high in various sectors like the automobile and aircraft industries but high design efficiency is achieved only when it is complemented by appropriate material. In the list newer addition is MMCs (Metal Matrix Composites) which are favorable because of their lower cost achieved by cheaper reinforcement, easy processing, and capabilities of mass production. In recent days, the importance of semi-solid casting has been well accepted among various processing routes for aluminum alloys despite many challenges in terms of process parameters like porosity, agglomeration, non-uniform reinforcement particle distribution, low wettability, and engulfment, and this is a main consideration for the present work. Semi-solid casting is considered to be one of the most important and effective manufacturing processes of aluminum alloy for viable mechanical and metallurgical properties in the current perspective of product requirement and competitiveness. A glimpse of the current status is presented, which shows the potential of the process which can be utilized by the industries for several benefits. In a nutshell, it can be found that process has the capability of alteration by the use of different scraps and also have flexibility according to the processing parameters like stirring, pouring temperature, type of reinforcements, etc.
\end{abstract}

\section{Introduction}

The two or more materials namely "Matrix" and "Reinforcement" having different physical and chemical properties when mixed in a way that neither they fully fuse nor liquefy into one another, so despite they act jointly but remain dispersed are called composite [1-18]. Composites are mainly categorized into three groups as 1) Ceramic Matrix Composites (CMCs), a subgroup that consists of ceramic matrix and ceramic fibers [19-26]. As compared to old-style composites CMCs show tremendous improvement in fracture toughness, ductility, and thermal shock resistance. 2) Polymer Matrix Composites (PMCs), categorized into three categories thermoset, thermoplastic and rubber. They are used widely because of their low cost, easier fabrication methods, lower density as compared to metal \& ceramics, corrosion-resistant, and insulation properties. 3) Metal Matrix Composites (MMCs), which are the combination of metals and alloys as matrix and ceramics as reinforcement [27-32]. MMCs are majorly used composites among all categories.

MMCs show better mechanical and thermal properties like high strength, high-temperature resistance, and ductility on the other hand they depict low stiffness because of the strong but brittle properties of ceramic reinforcement particles [33-41]. For example, Al (Metal
Matrix) - SiC (refractory ceramic reinforcement in particle form) composite shows in-between mechanical and thermal properties as strength, wear resistance, electrical and thermal conductivity, coefficient of thermal expansion and stiffness, etc. as compare to matrix and reinforcement individual properties as mentioned in Table-1 [42-43].

Table-1: Properties of Al metal matrix and Si refractory reinforcement particles

\begin{tabular}{|l|c|c|}
\hline Properties & Al & SiC \\
\hline $\begin{array}{l}\text { Young Modulus } \\
\text { (GPa) }\end{array}$ & 70 & 400 \\
\hline $\begin{array}{l}\text { Yield Strength } \\
(\mathrm{MPa})\end{array}$ & 35 & 600 \\
\hline $\begin{array}{l}\text { Co-efficient of } \\
\text { Thermal } \\
\text { Expansion }\left(/^{\circ} \mathrm{C}\right)\end{array}$ & $24 \times 10^{-6}$ & $4 \times 10^{-6}$ \\
\hline
\end{tabular}

The matrix material and reinforcement phase are combined in solid-liquid mixed phases by various processing as shown in Figure-1. The reinforcement can be used in various forms like particles, short or long fibers, whiskers, or sheets. $\mathrm{SiC}, \mathrm{Al}_{2} \mathrm{O}_{3}, \mathrm{Si}_{3} \mathrm{~N}_{4}, \mathrm{~B}_{4} \mathrm{C}, \mathrm{TiB}_{2}$, and $\mathrm{TiC}$ are some mostly used particulates in MMCs fabrication. Due to the availability of a large range of particulates at low cost and easy processing methods in

* Corresponding author: devendraps.research@gmail.com 
recent times, MMCs have become the first-choice materials, mainly for the automobile and aerospace industries.

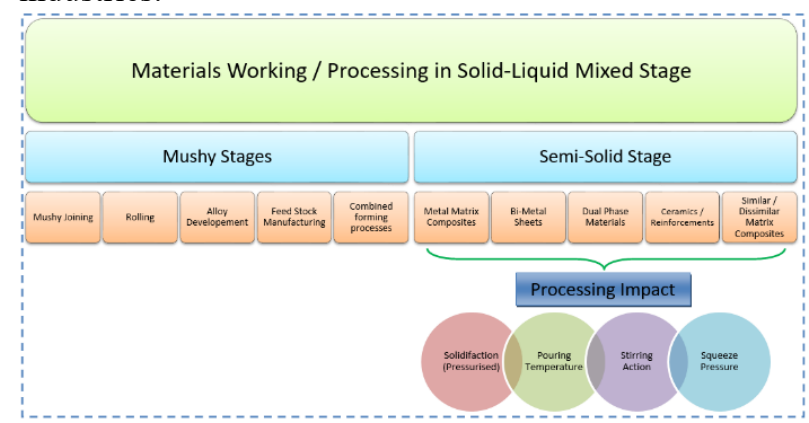

Figure 1: Material processing, parameters and application areas for solid-liquid mixed stage

The end properties of MMCs affected by the number of governing parameters such as processing method used, particulate size of reinforcement, heat treatment process, and volume fraction of matrix and reinforcement thus despite having better mechanical and physical properties, there are many concerning areas in processing like nonuniform distribution of reinforcement particulate, poor wettability, unwanted interface reactions, agglomeration, and porosity [44-45].

\section{Matrix Materials}

The matrix is a continuous, homogeneous, and monolithic material that provides a combining and holding medium for reinforcement to form the composite. The main function of matrix material is to save reinforcement against environmental damage and add aesthetic values to the obtained composite. Also, it serves as the medium for load transfer. For general purpose applications, metals like $\mathrm{Mg}, \mathrm{Ti}$, and their alloys are preferred as matrix materials while for explicit applications $\mathrm{Fe}, \mathrm{Cu}, \mathrm{Ni}$, and $\mathrm{Pb}$ can also be used but among all of these, $\mathrm{Al}$ and its alloys are the most popular matrix materials due to their availability, lower cost, lighter in weight, easy processing at low temperatures. They also possess good strength, toughness, and corrosion-resistant properties. But because of miserable tribological properties, their applications are limited. Recent progress in MMCs processing opens up new windows to develop light-weighted Al-based composites with the required balance of mechanical properties. For example, Figure-2 [46] shows significant improvement in mechanical properties of $\mathrm{Al}-\mathrm{Fe}$ composite as compared to basic $\mathrm{Al}$ matrix when $\mathrm{Fe}$ is added in different volume faction and different wire arrangement.

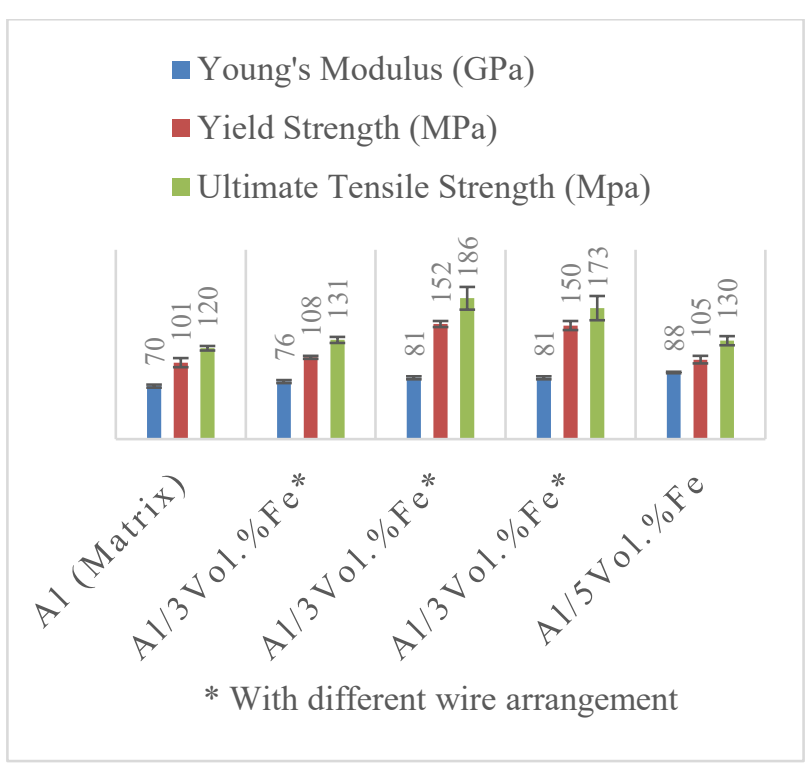

Figure-2: Variation in mechanical properties of Al-Fe composite with different volume fraction.

In previous years many aluminum alloys have been tried as a matrix. Amongst these Al-Si casting alloys, for example, A356, A357, A390, and LM6 are widely used in the automobile industry and military applications due to high strength over weight ratio, excellent wear, and corrosion-resistant properties.

$\mathrm{Al}$ and $\mathrm{Si}$ can be mixed in the solid stage as well as in the liquid stage. Based on the proportion of $\mathrm{Si}$ as shown in Table-2 [47], Al-Si alloys are categorized into three classes namely hypoeutectic, eutectic and hypereutectic. It has been observed in studies that eutectic alloys are most cost-effective and can be cast easily. For attaining specific and improved microstructural properties like refine grain size and altered morphology of Si phase, further alloying elements like $\mathrm{Cu}, \mathrm{Mg}$, etc. can be added which reduce the defects and also increase the fatigue and wear properties.

Table-2: Classification of Al-Si alloy based on $\mathrm{Si} w \mathrm{w} \%$

\begin{tabular}{|c|c|}
\hline Type of Alloy & Si wt $\%$ \\
\hline Hypoeutectic & $<11.7 \mathrm{wt} \%$ \\
\hline Eutectic & $11.7 \mathrm{wt} \%$ to $12.6 \mathrm{wt} \%$ \\
\hline Hypereutectic & $>12.6 \mathrm{wt} \%$ \\
\hline
\end{tabular}

\section{Reinforcement Materials}

To enhance the physical properties of the final composite, two or more materials added to the matrix material are called reinforcement. When more than one reinforcement is used, the obtained composite is called hybrid composite. For example, studies reported that graphite reinforcement in the $\mathrm{Al}$ matrix enhance wear properties but reduces mechanical strength. On the other hand, the inclusion of silicon carbide increases mechanical strength, wear resistance but also increases brittleness. Thus, $\mathrm{SiC}$ is 
being used as a secondary reinforcement in Al-Gr composite to optimize desired properties hence form the hybrid composite. Apart from reinforcement, fillers and additives are also incorporated in composite to get some specific characteristics or for reducing cost.

Reinforcement in various forms like fibers or whiskers, particles, and sheets have been tested. Early studies were attracted toward boron fibers, tungsten filaments, alumina, and beryllium for structural applications while in the starting 70 s researchers were more focused on carbon and ceramic fibers due to their lower cost. Recently glass fibers, metal fibers, aramid fibers, and natural fibers like sisal, hemp, flax, etc. are being used largely to improve strength and strength-toweight ratio. Characteristics of fiber reinforcement composite depend upon the length of fibers, their orientation corresponding to the direction of load application, and volume fraction. In parallel $\mathrm{SiC}, \mathrm{Al}_{2} \mathrm{O}_{3}$, $\mathrm{Si}_{3} \mathrm{~N}_{4}$, and $\mathrm{TiC}$ particulates also investigated extensively for tailored material properties, manufacturing flexibility, high tensile strength at elevated temperature, and low density. SiC reinforcement shows high-temperature stability and hardness hence used for bearings, pump components, rocket injector grooves to the furnace rollers, and components of exchanger tube. While $\mathrm{Al}_{2} \mathrm{O}_{3}$ is generally preferred mainly in the electronics industry and for packaging materials because of very good electrical insulation, Bioinert, and food compatible properties.
The effect of reinforcement in improving mechanical and microstructural properties is shown in Table-3 [4858]. It is observed that the addition of TiB2 in A356 Al$\mathrm{Si}$ alloy restricts eutectic $\mathrm{Si}$ growth (coarsening rate reduced by $32 \%$ ) and refines microstructure which enhances mechanical properties [49] while the addition of $\mathrm{B} 4 \mathrm{C}$ results in a decrement in roundness and the average size of $\alpha \mathrm{Al}$ particles with improved hardness, elongation and tensile strength of the composite [51]. On the other hand, powder chip reinforcement of Si in LM6 alloy resulted in better interfacial bonding and uniform distribution of un-melted solid reinforcement chips in the cavity to reduce porosity [50]. Base material itself can be used as reinforcement. For example, when A390 was added with $\mathrm{Al}$ powder $10 \%$ by weight caused the reduction of primary $\mathrm{Si}$ size by $70 \%$ results in a $20 \%$ increment in hardness and 50\% decrement in weight loss when processed by the cooling slope method [56]. when solid fraction casting is investigated in the case of AA6061 with added micro nanoparticles of AA6061 and compared with the conventional casting method, observation shows better mechanical properties and less porosity [52]. High reinforcement agglomeration, the reduced gap between gains, and significantly improved mechanical properties (tensile strength, impact strength) has been observed due to $4 \% \mathrm{Al}_{2} \mathrm{O}_{3}$ addition in a base matrix material (AA6061) [58].

Table-3: Effect of reinforcement on mechanical and microstructural properties

\begin{tabular}{|c|c|c|c|c|c|c|c|c|}
\hline $\begin{array}{c}\text { Matrix } \\
\text { Material }\end{array}$ & Reinforcement & $\begin{array}{c}\text { Tensile Strength } \\
\text { (MPa) }\end{array}$ & $\begin{array}{l}\text { Yield } \\
\text { Strength } \\
\text { (MPa) }\end{array}$ & $\begin{array}{c}\text { Impact } \\
\text { Strength } \\
\left(\mathbf{K J} / \mathbf{m}^{2}\right) \\
\end{array}$ & $\begin{array}{c}\text { Fatigue } \\
\text { Strength } \\
\text { (MPa) }\end{array}$ & Hardness & $\begin{array}{c}\text { Key } \\
\text { Observations }\end{array}$ & $\begin{array}{c}\text { Reference } \\
\text { No. }\end{array}$ \\
\hline AA2024 & $\mathrm{TiB}_{2}$ & 342 & 230 & ------- & ------- & $147 \mathrm{VH}$ & $\begin{array}{l}\text { Attained non } \\
\text { dendritic } \\
\text { composite in } \\
\text { semi solid } \\
\text { temperature } \\
\text { region } \\
\text { followed by } \\
\text { solution heat } \\
\text { treatment and } \\
\text { aging has } \\
\text { improved } \\
\text { mechanical } \\
\text { properties } \\
\text { (tensile } \\
\text { strength, yield } \\
\text { strength and } \\
\text { hardness). }\end{array}$ & 48 \\
\hline A356 & $\mathrm{TiB}_{2}$ & 184.15 & ------- & ------- & ---- & ------- & $\begin{array}{c}\mathrm{TiB}_{2} \\
\text { reinforcement } \\
\text { restrict } \\
\text { eutectic Si } \\
\text { growth } \\
\text { (coarsening } \\
\text { rate reduced } \\
\text { by } 32 \% \text { ) and } \\
\text { refines } \\
\text { microstructure }\end{array}$ & 49 \\
\hline
\end{tabular}




\begin{tabular}{|c|c|c|c|c|c|c|c|c|}
\hline & & & & & & & $\begin{array}{c}\text { which enhance } \\
\text { mechanical } \\
\text { properties. }\end{array}$ & \\
\hline LM6 & $\mathrm{Si}$ & 181.67 & 75.67 & ------- & ------- & $\begin{array}{c}68 \pm \\
3.13 \\
(\mathrm{BHN})\end{array}$ & $\begin{array}{l}\text { Powder chip } \\
\text { reinforcement } \\
\text { resulted better } \\
\text { interfacial } \\
\text { bonding and } \\
\text { uniform } \\
\text { distribution of } \\
\text { un-melted } \\
\text { solid } \\
\text { reinforcement } \\
\text { chips in the } \\
\text { cavity to } \\
\text { reduce } \\
\text { porosity. }\end{array}$ & 50 \\
\hline A356 & $5 w t . \% B_{4} C$ & 186 & ------- & ------ & ------- & $98 \mathrm{HV}$ & $\begin{array}{c}\text { Addition of } \\
\text { B4C results } \\
\text { decrement in } \\
\text { roundness and } \\
\text { average size of } \\
\alpha \mathrm{Al} \text { particles } \\
\text { with improved } \\
\text { hardness, } \\
\text { elongation and } \\
\text { tensile } \\
\text { strength of } \\
\text { composite. }\end{array}$ & 51 \\
\hline AA6061 & $\begin{array}{c}\text { Micro nano } \\
\text { particles of } \\
\text { AA6061 }\end{array}$ & $\begin{array}{c}550 \\
\text { (Compressive) }\end{array}$ & ------- & 19 & ------- & $\begin{array}{c}93 \\
\text { BHN }\end{array}$ & $\begin{array}{c}\text { when solid } \\
\text { fraction } \\
\text { casting is } \\
\text { investigated } \\
\text { and compared } \\
\text { with } \\
\text { conventional } \\
\text { casting } \\
\text { method, } \\
\text { observation } \\
\text { shows better } \\
\text { mechanical } \\
\text { properties and } \\
\text { less porosity. }\end{array}$ & 52 \\
\hline A357 & ------- & 380 & ------- & -------- & 180 & ------- & $\begin{array}{c}\text { A357 SSM } \\
\text { shows smaller } \\
\text { grain size and } \\
\text { larger grain } \\
\text { boundaries } \\
\text { which act as } \\
\text { an obstacle to } \\
\text { smaller crack } \\
\text { propagation } \\
\text { results } \\
\text { improved } \\
\text { fatigue } \\
\text { strength. } \\
\end{array}$ & 53 \\
\hline $\mathrm{Al}$ & $10 \mathrm{Cu}$ & ------- & ------- & ------- & ------- & $\begin{array}{c}103.96 \\
( \pm 3.9) \\
\text { VH }\end{array}$ & $\begin{array}{l}\text { Hardness and } \\
\text { grain size are } \\
\text { affected in } \\
\text { semi solid } \\
\text { region by }\end{array}$ & 54 \\
\hline
\end{tabular}




\begin{tabular}{|c|c|c|c|c|c|c|c|c|}
\hline & & & & & & & $\begin{array}{c}\text { annealing at } \\
\text { higher } \\
\text { temperature } \\
\text { for high period } \\
\text { of time. }\end{array}$ & \\
\hline JISADC12 & ------- & 350 & ------- & ------- & 90 & ------- & $\begin{array}{l}\text { High ductility } \\
\text { and high } \\
\text { strength are } \\
\text { visible with } \\
\text { the HMC } \\
\text { process } \\
\text { because } \\
\text { uniform } \\
\text { crystal } \\
\text { structure does } \\
\text { not change } \\
\text { with heating } \\
\text { process. }\end{array}$ & 55 \\
\hline A390 & $\begin{array}{c}\mathrm{Al}-10 \mathrm{wt} \% \\
\mathrm{Ti}\end{array}$ & ------- & ------- & ------- & ------- & $114 \mathrm{HV}$ & $\begin{array}{c}\text { With the } \\
\text { reduction of } \\
\text { primary } \mathrm{Si} \\
\text { size by } 70 \% \\
\text { there is } 20 \% \\
\text { increment in } \\
\text { hardness and } \\
50 \% \\
\text { decrement in } \\
\text { weight loss } \\
\text { when } \\
\text { processed by } \\
\text { cooling slope } \\
\text { method. }\end{array}$ & 56 \\
\hline AA6061 & $\mathrm{Al}_{2} \mathrm{O}_{3}$ & 172 & 131 & 17.91 & ------- & ------- & $\begin{array}{l}\text { High } \\
\text { reinforcement } \\
\text { agglomeration, } \\
\text { reduced gap } \\
\text { between gains, } \\
\text { and significant } \\
\text { improved } \\
\text { mechanical } \\
\text { properties } \\
\text { (tensile } \\
\text { strength, } \\
\text { impact } \\
\text { strength) has } \\
\text { been observed } \\
\text { due to } 4 \% \\
\mathrm{Al}_{2} \mathrm{O}_{3} \text { addition } \\
\text { in base matrix } \\
\text { material. }\end{array}$ & 58 \\
\hline
\end{tabular}

\section{Wettability in between matrix and reinforcement}

The reinforcement-matrix interface, solid and liquid combined physically, chemically, and mechanically in diffusion zone. Interfacial adhesion plays a fundamental role and governs the mechanical characteristics of the composite. The main function of reinforcement to carry the applied load which is transferred and distributed by the matrix, who binds the reinforcement together. For a strong interface, good wettability is required. The sessile drop experiment (Figure-3) describes the conditions of spreading of matrix melt over the surface of reinforcement substrate. The interface surface tensions (liquid-gas, solid-gas, and solid-liquid) are shown in figure 3 . Wettability is measured in terms of contact angle. $90^{\circ}$ is the threshold value in wettability measurement. A lower contact angle shows good wettability while a contact angle greater than $90^{\circ}$ represents poor wettability. 
Theoretically, $0^{\circ}$ contact angle required for instantaneous particle entry which is a total spreading condition but practically this can be achieved at the value of contact angle below $5^{\circ}$.
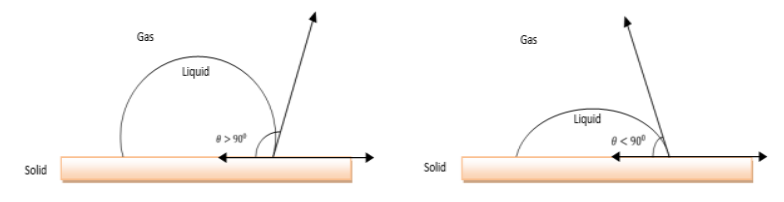

Figure 3: Conditions of good and poor wettability

Many techniques have been suggested by researchers previously to increase wettability. Keeping high energies of solid surface, lowering the surface tension of liquid phase, and reducing solid-liquid interfacial energy are few of them. Stirring also helps to improve wettability in AlSi alloy composite at the semi-solid stage. The use of magnesium as secondary reinforcement also helps to improve wettability but $\mathrm{wt} \%$ of $\mathrm{Mg}$ should not exceed more than $1 \%$ which causes an increment in slurry viscosity and corresponding decrement in wettability and can alter the microstructure as well. $\mathrm{Mg}$ also reduces agglomeration tendency by reacting oxygen present on the reinforcement particle surface, thinning the gas layer to improve wettability. However, neither interaction of $\mathrm{Mg}$ with nitrogen is the clear nor optimum magnitude of $\mathrm{Mg}$ and Si components [44].
Many complex and interrelated factors govern the properties of composite materials. One of the most influencing factors which alter MMCs properties drastically are processing temperature and holding time. High processing temperature alters matrix composition and reaction kinetics and also increases fracture strength gradually but also increases the $\mathrm{Si}$ concentration at the interface which causes an increment in hardness towards the interface. The effect of processing temperature on microstructural and mechanical properties of various $\mathrm{Al}$ alloys with different reinforcement is investigated. $555^{\circ} \mathrm{C}$ and $615^{\circ} \mathrm{C}$ are the solidus and liquidus temperatures of A356 alloy respectively but for Smoother slurry flow the optimum pouring temperature is $610^{\circ} \mathrm{C}$ [4]. By adding Strontium ( $\mathrm{Sr}$ ) as reinforcement in $\mathrm{A} 356$, the conversion of dendric microstructure into non-dendric at $625^{\circ} \mathrm{C}$ resulted in using liquidus casting for unmodified as well as modified (eutectic) A356 [61]. At the time of eutectic reaction, the undercooling temperature is lower down as compared to base alloy when $5 \% \mathrm{TiB}_{2}$ is used as reinforcement in A356 [5]. In microstructure shape factor and circular diameter reduces as pouring temperature lower down. Some other Al alloys were investigated for different temperature ranges and observations stated in Table-4 [59-66]. Decreased pouring temperature leads to the formation of globular primary $\alpha$-Al grains but with lost sphericity and decreased particle size. Viscosity increased with lower temperature in the rheo-die casting direction of semi-solid slurry. When solid fraction slurry is at around 30 to $35 \%$ of cooling slope, it gives optimized results [67-71]

\section{Impact of Temperature}

Table-4: Effect of pouring temperature with various reinforcement

\begin{tabular}{|c|c|c|c|c|c|c|c|}
\hline $\begin{array}{c}\text { Matrix } \\
\text { Material }\end{array}$ & Reinforcement & $\begin{array}{c}\text { Temperature } \\
\left({ }^{\circ} \mathrm{C}\right)\end{array}$ & $\begin{array}{l}\text { Density } \\
\left(\mathrm{Kg} / \mathrm{m}^{3}\right)\end{array}$ & $\begin{array}{c}\text { Specific } \\
\text { Heat } \\
(\mathbf{j} / \mathbf{K g} / \mathbf{K}) \\
\end{array}$ & $\begin{array}{c}\text { Thermal } \\
\text { Conductivity } \\
(\mathbf{w} / \mathbf{m} / \mathbf{K})\end{array}$ & Key Observations & $\begin{array}{l}\text { Reference } \\
\text { No. }\end{array}$ \\
\hline A356 & ------- & $\begin{array}{c}555 \\
\text { (Solidus) } \\
615 \\
\text { (Liquidus) }\end{array}$ & $\begin{array}{c}2700 \\
\text { (Solid) } \\
2795 \\
\text { (Liquid) }\end{array}$ & 1082 & $\begin{array}{l}160 \text { (Solid) } \\
60 \text { (Liquid) }\end{array}$ & $\begin{array}{l}\text { For Smoother } \\
\text { slurry flow the } \\
\text { optimum pouring } \\
\text { temperature is } \\
610^{\circ} \mathrm{C} \text {. }\end{array}$ & 59 \\
\hline ADC 12 & ------- & $\begin{array}{c}520 \\
\text { (Solidus) } \\
572 \\
\text { (Liquidus) }\end{array}$ & ------- & -- & ------- & $\begin{array}{c}\text { Decreased } \\
\text { pouring } \\
\text { temperature leads } \\
\text { to the formation } \\
\text { of globular } \\
\text { primary } \alpha-\mathrm{Al} \\
\text { grains but with } \\
\text { lost sphericity } \\
\text { and decreased } \\
\text { particle size. }\end{array}$ & 60 \\
\hline A380 & ------- & $\begin{array}{c}525 \\
\text { (Solidus) } \\
596 \\
\text { (Liquidus) }\end{array}$ & ------- & ------- & ------- & $\begin{array}{l}\text { A slight change } \\
\text { in size and no. of } \\
\text { primary } \alpha-\mathrm{Al} \\
\text { grains is observed } \\
\text { with decreased }\end{array}$ & 61 \\
\hline
\end{tabular}




\begin{tabular}{|c|c|c|c|c|c|c|c|}
\hline & & & & & & $\begin{array}{c}\text { pouring } \\
\text { temperature. }\end{array}$ & \\
\hline $\mathrm{Al}$ & 25 mass\% Si & $\begin{array}{c}577 \\
\text { (Solidus) } \\
760 \\
\text { (Liquidus) }\end{array}$ & ------- & ------- & ------- & $\begin{array}{l}\text { Change in } \\
\text { viscosity is } \\
\text { reciprocal with } \\
\text { shear rate. }\end{array}$ & 62 \\
\hline $\mathrm{Al}$ & $20 \mathrm{Si}$ & ------- & ------ & -----. & ------- & $\begin{array}{c}\text { Wear rate } \\
\text { depends mostly } \\
\text { upon load but } \\
\text { sliding velocity } \\
\text { and sliding } \\
\text { distance is also } \\
\text { influencing } \\
\text { factors. }\end{array}$ & 63 \\
\hline $\begin{array}{c}\text { A380 } \\
\text { (YL112) }\end{array}$ & -------' & $\begin{array}{c}525 \\
\text { (Solidus) } \\
797 \\
\text { (Liquidus) }\end{array}$ & ------- & ------ & ---- & $\begin{array}{c}\text { Viscosity } \\
\text { increased with } \\
\text { lower } \\
\text { temperature in } \\
\text { rheo-die casting } \\
\text { direction of semi } \\
\text { solid slurry. } \\
\end{array}$ & 64 \\
\hline $\mathrm{AlSi}_{9} \mathrm{Mg}$ & ------- & $\begin{array}{c}546 \\
\text { (Solidus) } \\
598 \\
\text { (Liquidus) }\end{array}$ & ------ & ---- & ----- & $\begin{array}{c}\text { Increased no. of } \\
\text { oscillation period } \\
\text { produces } \\
\text { globular, fine and } \\
\text { uniform } \\
\text { microstructure } \\
\text { when semi solid } \\
\text { slurry is prepared } \\
\text { by Intermediate } \\
\text { Frequency } \\
\text { Electromagnetic } \\
\text { Oscillation } \\
\text { Process. }\end{array}$ & 65 \\
\hline A356 & ------- & $\begin{array}{c}570 \\
\text { (Solidus) } \\
615 \\
\text { (Liquidus) }\end{array}$ & 2495 & 1082 & $\begin{array}{c}60 \text { (Solid) } \\
160 \text { (Liquid) }\end{array}$ & $\begin{array}{l}\text { When solid } \\
\text { fraction slurry is } \\
\text { at around } 30 \text { to } \\
35 \% \text { of cooling } \\
\text { slope, it gives } \\
\text { optimized result. }\end{array}$ & 66 \\
\hline
\end{tabular}

\section{Conclusions}

The paper discussed key features of MMCs and contributing process parameters of $\mathrm{Al}$ alloy composites with various reinforcement processed with semi-solid casting method. The reviewed work summarized as follows:

- In modern industrial applications, MMCs are a very popular choice because of their costeffectiveness (achieved by cheaper reinforcement), ease of processing, and mass production. Despite several processing challenges like ununiform particle distribution, agglomeration, porosity, low wettability, and occurrence of undesired interfacial reactions, stir casting is the most economical method for processing MMCs.
- Some critical parameters like type of reinforcement, volume fraction, processing temperature, holding time and wettability, contributes to improving mechanical and microstructural properties. Sometimes secondary reinforcement can also be used to get tailored material properties. For example, $1 \mathrm{wt} \%$ $\mathrm{Mg}$ is used with $\mathrm{SiC}$ reinforcement to improve wettability along with enhancement of mechanical properties.

- Also, wettability can be increased by maintaining the high energy of solid surfaces, by lowering down the surface tension of the liquid matrix, and by reducing solid-liquid interfacial energy at the matrix reinforcement interface.

- Temperature is another critical process parameter in semi-solid casting. Decreased pouring temperature leads to the formation of 
globular primary $\alpha$-Al grains but with lost sphericity and decreased particle size.

\section{References:}

1. M.O. Shabani, A. Baghani, A. Khorram, et al. Silicon online (2020).

2. J. Santos, L.H. Kallien, A.E.W. Jarfors, Metall and Mat Trans A 49, 4871 (2018)

3. M Agarwal, $\mathrm{R}$ Srivastava, Materials and manufacturing processes 31, 1958-1967 (2016)

4. J. Nampoothiri, C. Muthuraja, I. Balasundar, Trans Indian Inst Met 71, 2707 (2018)

5. M Agarwal, $\mathrm{R}$ Srivastava, Materials and Manufacturing Processes 34, 462 (2019)

6. K. Prapasajchavet, Y. Harada, S. Kumai, Metalcast 11, 123 (2017)

7. F. Sheykh-jaberi, S. L. Cockcroft, D. M. Maijer, A. B. Phillion, Journal of Materials Processing Technology, 266, 37 (2019)

8. M. Agarwal, A. Singh, R. Srivastava, Transactions of the Indian Institute of Metals 71, 1091 (2018)

9. M. Agarwal, J. Shukla, A. K. N. Shukla et al., 10th International Conference of Materials Processing and Characterization, Materials Today: Proceedings 26, 556-560 (2020)

10. Y. Hu, Y. Nan, L. Zhao, D. Liu, International Journal of Cast Metals Research 31, 346 (2018)

11. O. Lashkari, R. Ghomashchi, Canadian Metallurgical Quarterly 53, 47 (2014)

12. M. Agarwal, R. Srivastava, Silicon 11, 355 (2019)

13. D. R. Johnson, C. McCleary, M.J.M. Krane, Inter Metalcast, 10, 147 (2016)

14. A. Mazahery, M.O. Shabani, Trans Indian Inst Met,65, 145 (2012)

15. S. Simlandi, N. Barman, H. Chattopadhyay, Trans Indian Inst Met, 65, 809 (2012)

16. A. K. Sajjad, S. Ji, Critical Reviews in Solid State and Materials Sciences 45, 171 (2020)

17. A. K. Sajjad \& S. Ji, Critical Reviews in Solid State and Materials Sciences 45, 1 (2020)

18. S.P. Nikanorov, V.N. Osipov, L.I. Regel, J. of Materi Eng and Perform, 28, 7302 (2019)

19. K. A. Guler, A. Kisasoz, G. Ozer, A. Karaaslan, Transactions of Nonferrous Metals Society of China 29, 2237 (2019)

20. M. Agarwal, R. Srivastava, Transactions of the Indian Ceramic Society 78, 94 (2019)

21. K. S. Alhawari, M. Z. Omar, M. J Ghazali, M. S. Salleh, M. N. Mohammed, Transactions of Nonferrous Metals Society of China 27, 1483 (2017)

22. M. Li, Y. Li, G. Bi, X. Huang, T. Chen, Y. Ma, Transactions of Nonferrous Metals Society of China 28, 393 (2018)
The authors declare that there is no financial and personal interest in this.

23. A. J. Avdani, A. H. Daei-Sorkhabi, Transactions of Nonferrous Metals Society of China 28, 1298 (2018)

24. Majhi J., Mandal A., Sahoo S.K., Patnaik S. C., Sarangi B., Jena K.P., $2^{\text {nd }}$ International Conference on Processing and Characterization of Materials, Materials Today: Proceedings 33, 5539 (2020)

25. S. H. M. Anijdan, M. Sabzi, Materials Science and Engineering: A 737, 230 (2018)

26. D.M. Wankhede, B.E. Narkhede, S.K. Mahajan, C.M. Choudhari, Materials Processing and characterization, 16th - 18th March, Materials Today: Proceedings 5, 17627 (2018)

27. A. Jahangiri, S.P.H. Marashi, M. Mohammadaliha, V. Ashofte, Journal of Materials Processing Technology 245, 1 (2017)

28. S. Chen, G. Chang, Yue, L. Xu-dong, Qing-chun, Transactions of Nonferrous Metals Society of China 26, 2247 (2016)

29. Y. Birol, Journal of Materials Processing Technology 186, 94 (2007)

30. Y. Birol, Journal of Materials Processing Technology, 207, 200 (2008)

31. Y. Birol, Journal of Alloys and Compounds, 473 (12), 133-138 (2009)

32. Y. Sui, K. Feng, C. Cheng, J. Wuhan Univ. Technol.-Mat. Sci. Edit, 31, 1105 (2016)

33. X. Luo, Y. Han, Q. Li, X. Hu, Y. Li, Y. Zhou, Journal of Wuhan University of Technology-Mater. Sci. Ed., 34, 1205 (2019).

34. S.R. Pulivarti, A.K. Birru, Trans Indian Inst Met, 71, 1735 (2018)

35. G. Li, W. Jiang, Z. Fan, Int J. Adv. Manuf. Technol., 91, 1355 (2017)

36. A. Guo, J. Zhao, C. Xu, J. of Materi. Eng. and Perform, 27, 2373 (2018)

37. S. Li, K. Sadayappan, D. Apelian, Metall. Mater. Trans., B 47, 2979 (2016)

38. X. Zhang, L.Fang, X. Geng, Z. Sun, H. Hu, X. Nie, Advances in Materials and Processing Technologies 4, 262 (2017).

39. M. Agarwal, R. Srivastava, Emerging Materials Research 8, 394 (2019)

40. A. Samadi, H. R. Shahbazkhani, International Journal of Cast Metals Research, 27, 129 (2013)

41. H. Huang, Y. X. Wang, P. H. Fu, L. M. Peng, H. Y. Jiang, W. Y. Xu, International Journal of Cast Metals Research, 26, 213 (2013)

42. J. Hashim, L. Looney, M.S.J. Hashmi, Journal of Materials Processing Technology, 92, 1 (1999)

43. M. Singla, D.D. Dwivedi, S. Lakhvir, V. Chawla, Journal of Minerals and Materials Characterization and Engineering, 8, 455 (2009) 
44. G. Zou, H. Zhang, Y. Yang, Trans. Indian Inst. Met., 73, 2511 (2020)

45. G. Liu, Q. Wang, L. Zhang, Metall. Mater. Trans. A, 50, 401 (2019)

46. V. Ganesh, M. Gupta, Scripta Mater. 44, 305 (2001)

47. D.L. Zalensas, Aluminum Casting Technology 2, AFS Inc.: Schaumberg, IL (1993)

48. S. Heneke, D. Benny, S.N. Karunakar, Appl. Sci., 1, $1501(2019)$

49. S. D. Kumar, M. Acharya, A. Mandal, Trans. Indian Inst. Met., 68, 1075 (2015)

50. M. Agarwal, R. Srivastava, Silicon, 11, 355 (2019)

51. J. Zhang, G. Ren-Guo, D. Tie, X. Wang, G. Xi-Hua, C. Ben-Chao, Y. Chen, Materials and Manufacturing Processes, 30, 340 (2015)

52. M. Agarwal, R. Srivastava, Materials and Manufacturing Processes, 31, 1958 (2016)

53. K. A. Ragab, M. Bouazara, A. Bouaicha, O. Allaoui, Materials Science and Technology, 33, 646 (2017)

54. A. Sahu, A. Behera, $4^{\text {th }}$ International Conference on Materials Processing and Characterization, Materials Today: Proceedings 2, 1175 (2015)

55. M. Okayasu, S. Takeuchi, T. Ochi, International Journal of Cast Metals Research, 30, 217 (2017)

56. M.M. Shehata, S. El-Hadad, M.E. Moussa, Inter. Metalcast., 15, 488 (2021)

57. D.R. Johnson, C. McCleary, M.J.M. Krane, Inter Metalcast., 10, 147 (2016)
58. M. Agarwal, R. Srivastava, Transactions of the Indian Ceramic Society, 78, 94 (2019)

59. P. Das, S.K. Samanta, S. Tiwari, Trans. Indian Inst. Met. 68, 1215 (2015)

60. S.K. Gautam, N. Mandal, H. Roy, J Braz. Soc. Mech. Sci. Eng., 40, 291 (2018)

61. Z. Liu, W. Mao, T. Wan, Met. Mater. Int., (2020)

62. Y. Fukui, D. Nara, N. Kumazawa, Metall. and Mat. Trans.. A 46, 1908 (2015)

63. M. Acharya, A. Mandal, Met. Mater. Int., 27,1578 (2021)

64. Z. Liu, G. Cui, T. Wan, Met. Mater. Int., (2020)

65. Q. Zhang, M. Cao, J. Cai, Journal of Materials Processing Technology, 215, 42 (2014)

66. A. Kolahdooz, S. Aminian, Journal of Materials Research and Technology, 8, 189 (2019)

67. M. Bouazara, A. Bouaicha, K. A. Ragab, J. of Materi Eng and Perform, 24, 3084 (2015)

68. S. Deepak Kumar, A. Mandal, M. Chakraborty, Int. J. Miner. Metall. Mater., 22, 389 (2015)

69. Ł. Rogal, Materials Science and Technology, 33,759 (2017)

70. B. Zhou, S. Lu, K. Xu, C. Xu, Z. Wang, B. Wang, Transactions of Nonferrous Metals Society of China 30, 318 (2020)

71. M. Agarwal, R. Srivastava, Advances in Materials and Processing Technologies, 1, 2020 